\title{
Maria Dudzikowa
}

\section{Obdarzanie obopólne. Refleksja na marginesie książki Steinera i paru innych lektur ${ }^{1}$}

George Steiner, historyk filozofii, literatury i kultury, sięgając do tych dyscyplin i do swoich półwiecznych doświadczeń nauczyciela akademickiego w książce Nauki mistrzów, z przekonaniem i pasją dowodzi, że „autentyczne nauczycielstwo jest powołaniem"2 i że

Nie ma umiejętności bardziej uprzywilejowanej. Nie ma piękniejszej przygody, niż rozbudzić moce drzemiące w innej osobie, wyzwolić marzenia sięgające dalej, niż ważył się śnić nauczyciel, rozpalić w drugim miłość do tego, co samemu się kocha. Kiedy rozrasta się rodzina uczniów, przywodzi to na myśl wypuszczanie coraz dalszych gałęzi przez starzejący się pień (...) Z niczym niepodobna porównać owej satysfakcji, która płynie z bycia pomocnikiem, zwiastunem rzeczy istotnych (s. 192-193).

To „wzniosłe poczucie powołania” (okr. autora, s. 9), nie odstępowało go przez całe nauczycielskie życie. O prowadzonym przez siebie w Genewie przez ćwierć wieku seminarium doktorskim Steiner pisze, że było jednym z jego "przywilejów, darów, nieporównanych z innymi aktów łaski i nadziei” i wyznaje, że dzisiaj, gdy jest na emeryturze „czuje się osierocony” (s. 27).

Korzystając z retoryki Steinera, jego słowa, jako wyjątkowo trafne, choć nie, pozbawione nutki patosu, odnieść mogę do swoich doznań związanych z Letnią Szkołą Młodych Pedagogów, nad którą „uprzywilejowana, nieporównywanie z innymi, sprawuję pieczę nieprzerwanie blisko ćwierć wieku.

1 Tekst jest przedrukiem z książki: E. Bochno, A. Korzeniecka-Bondar (red.) (2016). Naukowa wspólnota uczących się. XXX-lecie Letniej Szkoły Młodych Pedagogów przy Komitecie Nauk Pedagogicznych PAN. Białystok: Wydawnictwo Uniwersytetu w Białymstoku, s. 515-519.

2 G. Steiner (2007). Nauki Mistrzów, przeł. J. Łoziński, Poznań: Wydawnictwo Zysk i S-ka, s. 24. Wszystkie cytaty pochodzą z tego wydania, niektóre zaznaczam kursywą. 
Nie ma piękniejszej przygody... Z niczym nie podobno porównać satysfakcji”. Wszakże czy nie obawiam się „osierocenia”, którego doznał Steiner przechodząc na emeryturę? Nie. Choć już od paru lat jestem w tej grupie wiekowej co on i zamierzam w 2018 roku (moje dwie okrągłe rocznice: osiemdziesiąta urodzin i ćwierćwiecze kierowania LSMP) przekazać pieczę nad Szkołą komuś, kto w jej kręgu wzrastał ku samodzielności naukowej i będzie chciał oraz potrafił umacniać tworzoną przez lata kulturę naszej LSMP wzbogacając nowymi impulsami. Sam Steiner przecież pisze - powtórzmy: „kiedy rozrasta się rodzina uczniów, przywodzi to na myśl wypuszczanie coraz dalszych gałęzi przez starzejący się pień”.

Rodzina „Szkolników” (tak siebie żartobliwie nazywają) jest ogromna, rozgałęzienia liczne! Dwa z nich są mi wyjątkowo bliskie, są to: powołany przeze mnie przed 8 laty Zespół Samokształceniowy i Samopomocy Koleżeńskiej Doktorów przy KNP PAN oraz pączkująca z tej gałęzi grupa doktorów już habilitowanych, zmierzających we własnym rytmie „Ku profesurze” (nazwa podzespołu). W tych dwóch gremiach tak długo będziemy się spotykać na seminariach, jak długo trwać będziemy w radosnym przeświadczeniu o wzajemnej niezbędności w uwalnianiu wyobraźni naukowej i odwagi wyzwalającej transgresyjność. Jest to relacja „obopólnego obdarzania”, o którym mówi Steiner, zwracając uwagę, że

Najprawdziwszym darem ze strony Mistrza jest wskazanie uczniowi nierozwiązanego jeszcze problemu, niedowiedzionego twierdzenia (...) Czasem zmagają się z problemem wspólnie, czasem uczeń zdany jest tylko na własne siły (s. 126).

Steiner wyróżnia przy pewnym uproszczeniu trzy „podstawowe scenariusze czy struktury relacji” między nauczycielami (szeroko pojętymi) a uczniami (s. 9-10). Dwie pierwsze są toksyczne: (1) „Mistrzowie niszczą swoich uczniów i psychicznie i - co rzadsze - fizycznie. Łamią ich ducha, zawodzą nadzieję, wykorzystując ich zależność i indywidualność”. Z odwrotną sytuacją mamy do czynienia wtedy, gdy (2) „uczniowie, czeladnicy, podopieczni obalają mistrzów, zdradzają i rujnują. I ten dramat może mieć wymiar duchowy i fizyczny". W rozważaniach Steinera znajdujemy wiele przykładów takich toksycznych relacji zaczerpniętych $z$ historii filozofii, religii, socjologii, pedagogiki, a także z literatury pięknej. Zresztą, któż z nas ich nie zna $\mathrm{z}$ obserwacji najbliższego otoczenia czy nawet $\mathrm{z}$ autopsji? Zostawmy wszakże roztrząsanie tych kwestii na inną okazję.

Interesować nas będzie trzecia relacja nazwana metaforycznie przez Steinera „osmozą" (s. 10). Ona bowiem konstytuuje naszą LSMP i stanowi o jej kulturze, z namysłem i cierpliwie budowanej od momentu pierwszej Szkoły 
zorganizowanej przez prof. Okonia, kontynuowanej przez prof. Muszyńskiego (6 lat), a następnie przeze mnie ponad dwie dekady. Kultura ta, mówiąc słowami Steinera, to obdarzanie obopólne. Na czym ono polega? Oto:

Dzięki wzajemnemu oddziaływaniu, osmozie Mistrz czerpie od ucznia - kiedy go naucza. Intensywność tego dialogu rodzi przyjaźń w najgłębszym sensie (s. 10); Mistrz uczy się od uczniów i zmienia się sam w owej wzajemnej relacji, która w idealnej postaci jest procesem wymiany. Jak w labiryncie miłości, obdarzanie jest obopólne (s. 14, podkr. M.D.).

Jak uczy taki Mistrz? Zmuszając nas do wykraczania ponad siebie, poza siebie (s. 121).

Tu na myśl przychodzi psychologia transgresji przybliżona w tekstach Józefa Kozieleckiego. W swojej Autobiografii zpsychologia $w$ tle profesor pisze:

w 1982 roku odkryłem, że fundamentalną predyspozycją natury ludzkiej jest zdolność przekraczania istniejącego stanu rzeczy w świecie materialnym, poznawczym, społecznym i osobistym. Człowiek ciągle wychodzi poza granice swoich dotychczasowych osiągnięć, poza to, czym jest i co posiada. Dokonuje więc transgresji.

Opanowanie sił przyrody, odkrycia naukowe, rozwój sztuki, przeprowadzanie reform gospodarczych i edukacyjnych, łamanie tabu, konstrukcja nowoczesnej broni czy oryginalna praca nad własnym charakterem, to przykłady tego typu czynów. Dzięki nim ludzie tworzą subtelne struktury kultury i osobowości, dzięki nim czasem dokonują działań rujnujących i destrukcyjnych³.

A skoro tak, to wyzwalając transgresyjność, Mistrz, o którym mówi Steiner zapewne bierze pod uwagę jej ambiwalencję wskazaną wyżej sygnalnie ${ }^{4}$. Bo nie da się zrzucić z siebie odpowiedzialności i uchylać od ocen moralnych, jeżeli z powagą i szacunkiem traktuje się ucznia i pamięta o tym - co roztrząsa w swoich wykładach Barbara Skarga, a mianowicie, „w jakim miejscu ontologia najsilniej splata się z etyką"’.

Pozostańmy jeszcze chwilę przy transgresji, sięgając z kolei do zapisu rozmowy Kazimiery Szczuki z Marią Janion, która między 1981 a 1988 rokiem

3 J. Kozielecki, Moje wzloty i upadki. Autobiografia z psychologia w tle, Sopot: Gdańskie Wydawnictwo Psychologiczne, 2010, s. 157; patrz tenże: Koncepcja transgresyjna człowieka. Analiza psychologiczna, Warszawa: PWN, 1987, oraz tenże: Transgresja i kultura. Monografia, Warszawa: Wydawnictwo Akademickie Żak, 1999.

4 Kwestia ambiwalencji transgresji jako przekraczania granic jest bardziej złożona niż wynikałoby z opracowań Kozieleckiego. Patrz szerzej np. esej M. Lipowicza Od transcendencji człowieka do transgresji człowieka. Próba filozoficzno-socjologicznej konceptualizacji transhumanizmu, „Ethos” 111, lipiec - wrzesień 2015.

5 B. Skarga, Człowiek to nie jest piękne zwierzę, Kraków: Wydawnictwo Znak, 2007. 
wydała pięciotomową serię właśnie zatytułowaną Transgresje (Galernicy wrażliwości; Odmieńcy; Osoby; Maski; Dzieci). „Samo to słowo - zauważa Szczuka - wcześniej w ogóle nieużywane w polszczyźnie, stało się najbardziej uniwersalnym janionicznym słowem obok słowa fantazmat”. „Transgresorami" nazywano uczestników jej gdańskiego seminarium, w ramach którego pracowano nad tą serią, a praca, jak wspomina Janion, była bez wytchnienia, „mordercza”. Profesor nazywana przez uczestników swoich seminariów „Mistrzynią” (s. 19) wiele od nich wymagała. Wspomina:

faworyzowałam tych wszystkich samodzielnie myślących, którzy owszem brali, co proponowałam, ale umieli to spożytkować po swojemu i iść dalej (...) Najgorzej bywało z osobami, które wszystko przetwarzały na banały (...), chciałam żeby ludzie myśleli samodzielnie. Trzeba było przekłuwać balony samozadowolenia i nawiedzenia (s. 76-77).

Ale najwięcej wymagała od siebie:

Więc z odpoczynkiem bywało słabo. Budziłam się rano i pierwsze myśli, jakie pojawiały się w głowie, dotyczyły pracy. Co muszę przeczytać, wynotować, przetłumaczyć, przygotować (...)

Nie mogłam odpoczywać, bo zaraz miałam wyrzuty sumienia. Byłam jak ci pracownicy morza Wiktora Hugo. Wieczna praca. Nieskończona (s. 41-42).

"Obdarzanie obopólne”, którego znakomitym przykładem jest relacja profesor Janion z uczniami wymaga trudu obopólnego. O swoich sukcesach mówi ona ze skromnością wielkiej uczonej: „zostali profesorami, nauczycielami, pisarzami. Więc do czegoś się im przydałam" (s. 25). A oni? Jak wyznaje jeden z jej uczniów: „Mamy pewien rodzaj skazy. Ślad jej dotknięcia jest w nas, choć niektórzy chętnie by udawali, że go nigdy nie było" (s. 25).

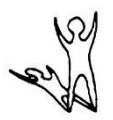

A jaki jest/będzie (i czy w ogóle) ślad dotknięcia Letnich Szkół Młodych Pedagogów na ich uczestnikach? Mistrzach i uczniach? Czas pokaże...

6 Transe - traumy - transgresje, t. 2: Prof. Misia. Z Marią Janion rozmawia Kazimiera Szczuka. Warszawa: Wydawnictwo Krytyki Politycznej, 2014, s. 151. Wszystkie cytaty zaczerpnięte $\mathrm{z}$ tego tomu.

7 Przyjaciele Marii Janion w nawiązaniu do jej najwcześniejszego dzieciństwa, nazywali ją za prof. Henrykiem Markiewiczem "prof. Misią" (s. 8). 